\title{
Phenomenological Analysis of Teachers' Organizational Deviance Experiences in a Rural Primary School in Turkey
}

\author{
Burcu Türkkaş Anasız ${ }^{1}$, Elif Iliman Püsküllüoğlu ${ }^{1}$ \\ ${ }^{1}$ Muğla Sitkı Koçman University, Faculty of Education, Turkey \\ Correspondence: Burcu Türkkaş Anasız, Muğla Sttkı Koçman University, Faculty of Education, Turkey.
}

Received: November 11, 2017

Accepted: December 12, 2017

Online Published: December 22, 2017

doi:10.11114/jets.v6i1.2783

URL: https://doi.org/10.11114/jets.v6i1.2783

\begin{abstract}
The purpose of this study was to analyze organizational deviance experiences of teachers. The study was in phenomenological design among qualitative research methods. In the research convenience sampling technique was used. The research was conducted in a rural primary school in Mugla province in Turkey. Nine teachers participated in the study, seven of them were women and two of them were men. The data of the study was collected via semi-structured interviews in 2015-2016 school year. In the exploration of the phenomenon, content analysis was used. According to the findings of the research, teachers experienced deviance on organizational and individual levels. The themes emerged on organizational level were production deviance and property deviance, and on individual level were political deviance and personal aggression. The codes appeared under production deviance were using long breaks and excusing absenteeism, and under property deviance was sabotage. The codes occurred under political deviance were gossip and favoritism in managerial processes, and under personal aggression was stealing colleague's ideas.
\end{abstract}

Keywords: deviance, organizational deviance, workplace deviance, school deviance, teachers

\section{Introduction}

If many people come and live together, act individually or collectively, then it is compulsory to constitute a number of rules. These rules facilitate being together and offer sample behavior patterns to the people in that community. People figure on how to behave, or not, by the help of these rules, and act according to them. When life goes on within the boundaries of these defined rules, it is thought that there is order and conformity. But it means that there is monotony, nothing new emerges and improves. On the contrary when acted differently, in other words, when nonconformity is shown, the community thinks that the existence and continuity of it are in danger. But it also shows that there are alternatives other than these defined rules. Besides, they enable the community to move in different directions that result in change and improvement.

Thoughts in the paragraph above are the product of peoples' living together for centuries and they also pave the way for the foundations of sociology. Today, these thoughts are called norms, social order, conformity, nonconformity or deviance. However, as it is seen, these phenomena are not new. Their existence can be traced as back as human history. When their theoretical foundations searched, it is understood that they started with the calls to constitute a discipline peculiar to the society. In the following years, the phenomenon such as crime or suicide rates tried to be explained through examining social situations like violation of societal rules (Traub and Little, 1999). With every trial to explain society, sociology developed. The concepts like the rules holding the society together, conformity to these rules and deviance from these rules, as foundations of this discipline, handled from the perspectives of different sociological theories. Among these concepts deviance was the basis of this study. Deviance is a familiar concept and also it can be accepted as a new phenomenon when studied in the boundaries of different sociological theories. In this study, deviance in organizations was analyzed. Analysis of deviance in educational organizations and deviance behaviors of teachers was the starting point of this research.

Deviance is any behavior different from accepted or defined rules. According to the level of this difference, dimensions of deviance also change. Deviance from written rules, i.e. deviance from laws, called as crime and necessities penal sanction. Deviance from unwritten rules, i.e. deviance from societal norms, results in exclusion and labeling in society. As it is seen these are negative deviance behaviors. On the other hand, if something new is wanted, it is accepted to not to obey the rules. The result of this behavior will be a new product and this deviance behavior is called positive. In this 
context, it is possible to say that there are both positive and negative deviance behaviors. In addition to the general explanations related to deviance, many people try to explain negative deviance in the context of sociological theories. One of them is anomie theory. In this theory, when the people in society do not have legal ways to reach their goals and when the continuity of the society is in danger, people disobey to societal rules and deviance emerges. There are also other sociological explanations of deviance such as control theory which stated that there must be conformity in order to secure social order; labeling theory draws attention to critical importance of labeling of the individual showing deviant behaviors; conflict theories deal with deviance as an outcome of social and economic injustice based on production; feminist theories conceptualize deviance as the result of gender inequalities. At the beginning, these theories were trying to find a ground to understand the sociological phenomenon. In other words they are in search of a common meaning. Then, they focused on why single individuals behave in this way (Appelbaum, Iaconi and Matousek, 2007; Dobbert and Mackey, 2015; Franzese, 2015; Goode, 2015; Traub and Little, 1999).

As it is seen, in one hand deviance is a familiar concept. On the other hand, it has strong sociological foundations and several theoretical explanations. Besides it has a diverse range of analysis field. One of them is organizations and workplaces. In this sense, organizational deviance is the violation of rules that exists in an organization. The main reason for calling the deviance as negative is related to the deliberate violation and its negative results for the organization. Organizational deviance or workplace deviance is discussed in many studies (Aksu, Gucer and Orcan, 2015; Bayin and Terekli-Yesilaydin, 2014; Bennet and Robinson, 2000; Demir, 2010; Girgin-Kose and Aksu, 2013; Iyigun and Cetin, 2012; Lawrence and Robinson, 2007; O'Neill, Lewis and Carswell, 2011; Robinson and Bennet, 1995). Organizational deviance or workplace deviance is the violation of ethical rules created in the organization (Sims, 2010). According to another definition, it is the violation of organizational norms, policies and internal rules (Appelbaum et al., 2007). In another definition, it is the deliberate violation of certain norms that endangers the organization and the well-being of its members. The violated norms in organizational deviance are the rules that are defined in order to reach organizational goals and resulted in organizational damage (Robinson and Bennet, 1995). The reasons for disobedience to organizational rules can be either unwillingness to conformity or motivations to violate (Kaplan, 1975).

While defining the dimensions of organizational deviance, at the beginning deviant behaviors are just sequenced. In the following years, reactions to these deviant behaviors are defined and dimensions are formed according to them (Robinson and Bennet, 1995). In the first study related to this subject, dimensions of deviance were analyzed under two headings, property deviance which means intentionally giving harm to organizational belongings and production deviance which means the violation of organizational rules that will affect quantity and quality of the product emerged (Hollinger and Clark, 1982). In another study, deviance was treated as a kind of counterproductive behavior that gives harm to employer's assets (Mangione and Quinn, 1975). In another study, conducted in recent years, deviance is analyzed through a framework, which has individual and organizational levels on the vertical axis, low and high levels on the horizontal axis (Robinson and Bennet, 1995). The current study is based on this framework. For this reason, it is thought that it is important to clarify what these levels are on horizontal and vertical axes (Robinson and Bennet, 1995):

Production deviance is on the organizational level on vertical axis and low level on horizontal axis. It stems from production deviance of Hollinger and Clark (1982). It is the violation of organizational rules. As the result of this violation, the product of the organization is worse by means of quality and quantity. Organizational harm is relatively less. Some of the production deviance behaviors are leaving work early, using long breaks, intentionally working slowly, wasting the sources of the organization.

Property deviance is on the organizational level on vertical axis and high level on horizontal axis. It stems from the counterproductive behavior of Mangione and Quinn (1975) and property deviance of Hollinger and Clark (1982). Property deviance is deliberately giving harm to organizational assets. Organizational harm is relatively more. Some of the property deviance behaviors are sabotage the organizational equipment, corruption and lying related to work hours.

Political deviance is on the individual level on vertical axis and low level on horizontal axis. Political deviance includes social interactions and behaviors that lead other employees to be disadvantageous individually and politically. Individual harm is relatively less. Some of the political deviance behaviors are favoritism, gossip, accusation, and rivalry.

Personal aggressiveness is on the individual level on vertical axis and high level on horizontal axis. Personal aggressiveness is showing hostile and aggressive behaviors to other employees. Individual harm is relatively more. Some of the personal aggressiveness behaviors are sexual harassment, verbal harassment, theft, endanger colleagues.

As it is mentioned in general deviance behaviors, the level also is important in organizational deviance behaviors. Organizational deviance either low or high, in long-term, may result in serious organizational problems. Organizations are together to actualize certain goals. When these goals are actualizing, it is important to use effectively both human 
resources and physical resources. Organizational deviance can be interpreted as being ineffective for several reasons. Managing physical and human resources effectively is critically important for educational institutions. Education is a process in which both the input and output is the individual and in which there is no alternative as wasting any resources. It can be claimed that even if its result cannot be observed immediately, in long-term it would result in a heavy cost.

Generally in organizations, deviance is studied with variables such as justice (Alias, Rasdi and Said, 2011; Ayazlar and Guzel, 2013; Brienza and Bobocel, 2017; O’Neill et al., 2011; Yesiltas, Ceken, and Sormaz, 2012); gender inequality (Akyuz and Ozyer, 2016); work-life quality (Sezici, 2014); emotional exhaustion (Brienza and Bobocel, 2017); emotional intelligence (Demir, 2010); power (Lawrence and Robinson, 2007; Sims, 2010); job satisfaction (Alias, Rasdi and Sais, 2011); turnover intention (Ayazlar and Guzel, 2013; Demir and Tutuncu, 2010; Sezici, 2014); personal characteristics (Guay et al., 2010; O'Neill et al. 2013); leadership (Yesiltas, Ceken and Sormaz, 2012); psychological contract (Iyigun and Cetin, 2012); organizational commitment (Guay et al., 2010); organizational citizenship behavior (Dunlop and Lee, 2004). These studies are quite important to make generalization and inferences related to the organizational deviance. It is also critically important to analyze organizational deviance deeply to clarify the subject. Besides, it is seen that organizational deviance is new in educational institutions and the number of the studies are limited (Aksu et al., 2015; Aksu, Gucer and Orcan, 2015; Aksu, 2016; Arbak, Sanli and Cakar, 2004; Argon and Ekinci, 2016; Enwereuzor, Onyishi, Onyebueke, Amazue and Nwoke, 2017; Turkkas-Anasiz, 2016; Waterhouse, 2004). All of them were taken into consideration and the purpose of this study was defined as analysis of teachers' organizational deviant behaviors. In accordance with this purpose, the questions below are defined:

1-On which dimensions do the teachers experience organizational deviance?

2-What do the teachers think about the reasons of organizational deviance?

3-How do the teachers react to organizational deviance?

\section{Method}

\subsection{Research Design}

This study was designed in phenomenology. Phenomenological design includes individuals' description of an experience related to a phenomenon. The individual is aware of this experience and the researcher tries to reach individual experiences of participants (Christensen, Johnson and Turner, 2015). So, in the current study in order to describe teachers' organizational deviance experiences deeply in its existing form, the phenomenological design was used.

\subsection{Participants}

While the participants of the study were defining, convenience sampling method was used. In this sampling style, the researcher chooses a case near and easily accessible (Yildirim and Simsek, 2011). In this context, an easily accessible school for the researchers was chosen. The chosen school was a small rural primary school in Mugla province in Turkey. In the school there were totally nine teachers. All of them voluntarily and sincerely accepted to participate in the study. Among the participants, seven of them were women and two of them were men. Inequality seen in the gender of participants was related to the school staff. Demographic variables related to the participant teachers were given in the table below.

Table 1. Gender and branch of the participants (teachers)

\begin{tabular}{lllllllll}
\hline & Turkish & English & Science & Math & Preschool & Primary & Arts & Music \\
Women & 1 & 1 & 1 & 1 & & 1 & 1 & 1 \\
Men & & 1 & & & 1 & & & \\
\hline
\end{tabular}

2.3 Data Collection Tool

In the study, semi-structured interview form was used. Semi-structured interview forms are important since they enable participants to express themselves (Buyukozturk, Kilic-Cakmak, Akgun, Karadeniz ve Demirel, 2012). Semi-structured interview form used in the study was developed in accordance with the purpose of the study and based on the literature review related to organizational deviance. Organizational deviance dimensions of Robinson and Bennett (1995) was taken into consideration. Before the semi-structured interview form was created, a large item pool consisting of open-ended questions was composed. Some of the questions were eliminated because they are not clear and relevant. Then these questions were structured as an interview form and sent to eight field experts for convenience. After their feedback, interview form was reorganized. In the interview form, there were three sections. In the first section, there were demographic variables. In the second section, there were four questions related to organizational deviance behaviors of teachers. Each of the questions included two more questions related to the reasons and reactions to these 
deviance behaviors. Totally, there were twelve questions related to organizational deviance behaviors of teachers. In the final section, there was suggestions and opinions section to listen to other opinions of the participants.

\subsection{Validity and Reliability}

In order to lessen validity and reliability concerns, after the feedbacks of field experts and the construction of semi-structured interview form, a pilot interview with a teacher was conducted. Besides, before each interview, short talks were carried out with participants in order to warm-up for the conversation. In every interview, it was stressed that their contribution was important for the research in order to make them feel important and relaxed. In order not to change the flow of the interview and not to manipulate the participants, researcher avoided personal inferences and judgments as much as possible. With the permission of the participants, in order not to lose any part of interviews, they were recorded. In order to reduce bias, recorded interviews were scripted and analyses were done according to them. Analyses were examined by a researcher other than the authors, then agreed themes and codes were reorganized. Besides, after themes and codes were defined, randomly chosen three interviews were coded again by both of the researchers. In this way, consistency between them was decided and it was calculated as .75. Lastly, in order to support codes, direct quotations of the participants were given.

\subsection{Data Collection Process}

Related to the nature of qualitative research, it may not be possible to purely objective. However, in order to improve the reliability, every step followed needs to be given clearly (Daymon and Holloway, 2002). In this context, in order not forget any detail, researcher diary was kept. In this diary, the environment of the interview, the time it took, attitudes and feelings of participants were noted. Before the interviews, teachers were asked for an appointment. Then according to the scheduled date and time, face-to-face interviews were held. Some of the interviews were held in either school garden or teachers' room. There was no time limit for participants. But each of the interviews took nearly 30 or 45 minutes. Interviews were taken under the guidance of the first author of the article. Before the interviews, it was emphasized that based on confidentiality and ethical concerns the information given in the scope of the research would not be shared with third persons. The participants were informed and asked for the consent of voice recording beforehand.

\subsection{Data Analysis}

According to Miles and Huberman (1994) in qualitative data analysis, there is no common rule that gives accurate results. For this reason, the researcher uses his analytical thinking skills and while exploring the phenomenon he uses his own creativity (Richardson, 2000). In the research, the data is analyzed via content analysis. After the voice records are transcripted, these data loaded to NVIVO 10 software to analyze. NVIVO 10 is software that facilitates analysis of qualitative data on the computer and it enables using multiple methods like video or voice record, observation, pictures, graphics (QSR International, 2012). The following steps were conducted on that software. Then the questions of the interview form and the dimensions of it were taken into consideration, a framework in which there were codes and themes were constituted. After that, every participant's interview data was coded under related theme separately.

\section{Findings}

In this section, findings of the current study are given. The findings are structured in the scope of the research questions and themes emerged in the study. The research questions are in which dimension teachers experience organizational deviance, what are the possible reasons for them and what is the reaction to these behaviors. According to the findings, teachers experienced deviance on organizational and individual levels. On the organizational level under production deviance theme giving long breaks and excusing absenteeism occurred, and under property deviance theme sabotage appeared. On the individual level under political deviance theme there were gossip and favoritism, and under personal aggressiveness theme stealing colleague's ideas emerged. Based on the themes, teachers' organizational deviance behaviors were analyzed. On each theme reasons and reactions of the deviant behaviors were given.

\subsection{On organizational Level - Production Deviance Theme -Giving Long Breaks and Excusing Absenteeism}

On organizational level under production deviance theme, teachers thought that long breaks were given $(\mathrm{n}=2)$. It is understood that generally, when coming back to the class from breaks, some of the teachers extended their breaks more than enough. O8 explained that situation "...Indeed we have 15 or 20 minutes breaks. However, some of the teachers go to their classes late, if there is no school administrator around...". So it can be inferred that teachers are tired, need more time to relax and there is no close inspection. So, they show deviant behavior. As the reasons for giving long breaks, weariness, burnout and non-effective use of time were given $(n=2)$. Teachers are tired and feel burnout, and their motivation decreases. So, as the result of educational and instructional activities, effective outcomes aren't produced. Indeed, $\mathrm{O} 2$ stated “...non-effective use of time for learning, teachers' being tired, following the same routines do not make their lessons efficient...". Teachers' feeling tiredness and being burnout prevent them to start their courses on time. 
As a result, it is difficult to have effective and efficient instructional outcomes. Teachers reacted to this deviant behavior as talking to the teacher showing it and warning him $(n=2)$. Teachers are not indifferent to this situation because they think that students are affected negatively. Indeed $\mathrm{O} 2$ stated that “... I would warn them, talk to them. If they continue these behaviors, students cannot learn anything and are affected negatively...". Teachers' reactions related to subject may lessen production deviant behaviors.

On organizational level under production deviance theme, teachers thought that absenteeism was excused $(n=2)$. Teachers stated that generally educational activities and lessons were conducted regularly as scheduled. However, when there was a forthcoming national exam, teachers gave priority to students' success in that exam. Therefore, they focused on extra instructional activities and postponed some of the bureaucratic things they have to do. As a result, in order to finish assigned bureaucratic papers, they did not come to work. Indeed O6 said, “...some of the teachers may not evaluate the exam results and homework papers during the term. At the end of the term, they put forward excuses like being ill and do not come to work...". Teachers thought that this behavior was shown because they had many things to do but limited time $(n=2)$. O4 expressed that "...lack of time... while teachers are spending most of their time on preparing students for the exams, they don't have time for bureaucratic things and then they pretend they are ill and not come to school...". As a reaction to this deviance behavior, teachers just warned their colleagues $(n=3)$. O4 stated that "...finding such a solution to his lack of time is like stealing students' time...".

\subsection{On Organizational Level - Property Deviance Theme -Sabotage}

On organizational level under property deviance theme, teachers stated that they experienced sabotage $(\mathrm{n}=1)$. Sabotage, mentioned there, was deliberately using viral USB devices on computers in common use in teachers' room. Related to the subject $\mathrm{O} 3$ stated that “....in teachers' room there is a computer for everybody's use. Even if we state that USB devices should be open after screening for the virus, some of our friends pay no attention to it. The software of the computer constantly collapses. Then we think that he does it intentionally...". The teacher experienced that deviant behavior stated that it resulted from a personal debate between two teachers. One of them was a teacher frequently using the computer and the other one was the person who deliberately uses the viral USB device. Because of the problem between them, instead of directly harming, he was trying to giving harm indirectly to him. However, from the perspective of the organization, personal problems reflected the organization and giving harm to the organization and its equipment. The other teachers were bothered because of this situation. As the reason of sabotage, ambition and grudge were shown $(\mathrm{n}=1)$. Related to the subject $\mathrm{O} 3$ stated that “... I think this stems from not preventing ambitious and animosity...". A teacher's giving harm to organizational property as if it was his own, instead of solving problems, is thought provoking. This situation may be related to teacher's negative mood. It was observed that as a reaction to sabotage, that person was warned $(n=1)$. Related to the subject $\mathrm{O} 3$ stated, “... both of them are our friends; there is nothing to do other than a warning. But if I were someone with authority, I definitely punished him...". As understood from this reaction, the participant thinks that this behavior should be punished but because of an emotional tie, like friendship, just a warning is shown. Since warning includes communication with that person, it can be assumed that it would help to solve the problem.

\subsection{On individual Level - Political Deviance Theme - Gossip and Favoritism}

On the individual level under political deviance theme teachers stated that they experienced gossip $(n=4)$. Related to the gossip behavior O1 used the expression “...we are actually a small and healthy school. Even if you are successful in a subject, you may have a fault. However, time-to-time, your success is forgotten and wherever your any small deficiency is seen, this overshadows your success and comes into prominence. Rumors behind become bigger and bigger...". The frequent experience of gossip among teachers may be related to the structure of the society. It is a common phenomenon in Turkey. Of course, it does not mean that this legitimizes gossip. Gossip is a phenomenon that produces negative outcomes in any community under every circumstance. As the reason of gossip bad temper was shown $(n=4)$. Teachers thought that individuals having negative mood demonstrated this behavior. Related to the subject $\mathrm{O} 9$ stated "....as much as I observed generally people, tend to make gossip, may have ambitions to be more successful. They are in a rivalry and even if they are aware this affects their psychology in bad manners...". It can be understood that suppressed negative emotions and attitudes may reflect the working environment. In other words, these people have bad manners, they are not satisfied with their life and working conditions and as a result, they gossip. As a reaction to gossip, teachers supported the person talked about $(\mathrm{n}=2)$ and communicated to him $(\mathrm{n}=2)$. Teachers supported the teacher gossiped about and stated that they were with him. Indeed, related to subject O9 expressed that “... I will go to that person gossiped and tell him the situation... I will say that if you want you can go, analyze and evaluate the situation..". Related to communication $\mathrm{O} 7$ stated that "... talk to the person who gossips, it is best to understand him... in order to understand why he is telling such things...". In both reaction styles, it is understood that teachers try to compose positive environment. This situation may be related to the positive school culture they have. Because it is known that in supportive school cultures, people tend to be constructive and positive behaviors. 
On the individual level, under political deviance theme, teachers sometimes experienced favoritism $(n=2)$. They stated that even if it didn't happen constantly and explicitly, especially in the beginning of school year and when educational programs were scheduled, favoritism was seen. In this subject, O5 told that “...in our school administrative work is done smoothly. However, sometimes even if you have reasonable excuses, your schedule is not arranged as you wish. Okay, it can be. But if everybody's program is arranged in accordance with their request, just one persons' program is not, what do you think about it?...". Favoritism to some of the teachers in that school is related to the current administration. For this reason, it can be said that the administration doesn't treat teachers fairly and build trust among them. Teachers thought that favoritism rooted in being from the same city $(\mathrm{n}=2)$. Related to the subject, O6 stated " ... in other words if you are from Mugla and I am from somewhere else, your administrative work is done more quickly. Because I always meet you after school or I have other common relationships. This has an effect on administration...". Teachers think that if they have any common ground with the administrator they may show favoritism. This situation is accepted as normal in most of the organizations in Turkey. Individuals do their bureaucratic works with using their common grounds. However, it needs to be stressed that in democratic and fair societies, there is no place for these concepts. As a reaction to favoritism, teachers supported the one who was not favored $(n=2)$. Related to the subject $\mathrm{O5}$ stated that "...if he is right if my friend thinks if some other one is favored, I can tell him to complain about the situation and talk to the upper administration. I can guide him...". This situation shows that in the school, teachers are not silent when any of them experience favoritism. Therefore, in that way, in an organization that is not silent, works will be more effective.

\subsection{On individual Level - Personal Aggressiveness Theme - Stealing Colleague's Ideas}

On the individual level under personal aggressiveness theme, it was stated that teachers experienced other teachers stealing colleague's ideas $(n=3)$. Stealing colleague's ideas meant teachers talk about any subject among them, later one of them pretended as if it was his own idea. Related to the subject, $\mathrm{O} 1$ stated “... everyone suggests his idea under normal conditions. But sometimes some of our friends share their brilliant ideas with us and any person tell it to the administrator or in another meeting as if it is his own views or he finds out it...". Teachers stated that even if it was not frequent they experienced it. It bothers them but it exists. Teachers thought that the reason of the situation was lack of self-confidence $(n=3)$. Teachers want to be successful all the time, but if they are not adequate, they use unethical ways to be so. In other words, someone who is inadequate in order to compensate for it may pretend to be successful without having any ethical concerns. For that reason, for inadequate teachers stealing colleague's ideas is not something bad. They try to satisfy themselves with behaving in this way. As a reaction to stealing colleague's ideas, just warning behavior was shown $(n=3)$. Related to the subject, $\mathrm{O} 1$ stated "... this subject is a bit snappish. Whatever you tell may be wrong and you may be guilty. If he says "No, I do not mean it", you may be accused. For this reason, at most I say that you should be careful about this subject...". In this context, even if it is known that the subject is important, in order not to be guilty as a result, other teachers just warn the one that steals colleague's ideas. It is understood that in this kind of warning, the person is kindly and implicitly criticized.

\section{Discussion, Results, and Suggestions}

The main purpose of this study was to analyze organizational deviance behaviors of teachers. According to the findings, organizational deviance behaviors, teachers experienced, grouped under themes of production deviance, property deviance, political deviance and personal aggressiveness. These themes were organizational and individual deviance behaviors in the literature (Bennet and Robinson, 2000; Robinson and Bennet, 1995). In related research (Akyuz and Ozyer, 2016; Argon and Ekinci, 2016; Enwereuzor, et al., 2017; Iyigun and Cetin, 2012; O’Neill et al. 2011), even if their levels change as low, middle or high, it is shown that organizational deviance is experienced on both organizational and individual levels. In this research, on the organizational deviance level, production deviance and property deviance appeared. On the individual level, political deviance and personal aggressiveness occurred. Findings emerged in the related theme were handled, in accordance with the purpose of the research as experienced behavior, the reason for it and the reaction to it.

According to the research findings, the first theme emerged was production deviance. Production deviance includes behaviors resulted in poor organizational outcomes because of working less or working without quality. According to the findings, teachers experienced production deviance as giving long breaks and excusing absenteeism. In Robinson and Bennet's (1995) research, possible behaviors resulted in production deviance are giving long breaks, reading newspapers in an empty room, talking instead of working, coming work late and leaving early, deliberately working slowly, even if not ill, pretend to be so and not come to work. In Arbak and others' (2004) study, other possible behaviors are being indifferent, absenteeism, making someone do your work, being careless, intentionally doing nothing related to the work. Giving long breaks shows similarity with Robinson and Bennet's (1995) findings. On the other hand, excusing absenteeism shows similarity with both Robinson and Bennet's (1995) and Arbak and others' (2004) findings. According to the findings, it was stated that the reason of giving long breaks may be weariness, burnout and 
non-effective use of time. These expressions of teachers overlapped related research in literature. In the study of Sezici (2014) as work-life quality decreases, organizational deviance behaviors increase. Similarly, in Brienza and Bobocel's (2017) and Enwereuzor and others' (2017) studies as emotional exhaustion increases, organizational deviance behaviors increase. Whatever it was stated as the reason for this behavior, teachers individually warn or talk to that teacher showing it. Similarly as an excuse for absenteeism, business was shown. Teaching profession necessitates individual awareness and societal responsibility. Besides as Celikten, Sanal and Yeni (2005) stated that day-by-day teachers' role in instructional activities raise. On one-hand curriculum changes and on the other hand bureaucracy make teachers more occupied. Nevertheless, being absent at work in order to do responsibilities is not something to be defended. Teachers stated that they just warned their colleague when they saw someone excusing their absenteeism. Warning or talking to people, that shows certain kind of behaviors; seem to be the only thing to do. However, especially in educational institutions behaviors that leads to production deviance need to be treated sensitively. Production deviance means that quantity of the work will be lessened and quality of the work will be worse. Production deviance in educational institutions means that both quality and quantity will be affected and problematic behaviors will emerge. For instance, if a teacher does not come to work in order to finish paper works at the end of the school year, students will not come to school, either. Even if at the end of the school year, instructional activities are ended, the only purpose of the school is not teaching. As the result of attendance, students get educated and are socialized. So, whatever its reasons are, production deviance in education will be resulted in negative outcomes in the long term. For this reason, both teachers and administrators should treat this subject carefully. Teachers should try to avoid behaviors that may lead to production deviance. On occasions it is not possible to be avoided, finding someone else to their places may help to lessen the negative outcomes.

According to the findings, the second theme emerged was property deviance. Property deviance includes behaviors giving harm to concrete and discrete assets of the organization. According to the findings, teachers experienced property deviance as sabotage. The other possible property deviance behaviors emerged in other studies are wasting workplace sources, using organizational sources for his own affairs, using privilege peculiar to the organization for personal matters, keeping equipment in common use, showing behaviors that lead to organizational division (Arbak et al., 2004; Robinson and Bennet, 1995). According to the findings as the reason of sabotage, ambition and grudge was shown. These characteristics are personal. In the related research, it is also suggested that deviant behaviors may be related to personal characteristics. In this context, Guay and others' (2010) research findings show that agreeableness and conscientiousness as personal characteristics are in a negative relationship with organizational deviance. In Alias and others' (2011) study, it is put forward that personal characteristics have an effect in organizational deviance behaviors. But if the working conditions trigger, organizational deviance behaviors emerged. On the other hand in the findings of O'Neill and others' (2011) study, it is stated that personal characteristics are more important than the organizational environment. When the relationships between organizational environment and organizational deviance is taken into consideration, it is understood that there are research findings stating that as organizational commitment decreases (Guay et al., 2010), organizational deviance behaviors increases. And also as organizational justice perception decreases (Alias et al., 2011; Ayazlar and Guzel, 2013; Brienza and Bobocel, 2017; Yesiltas et al., 2012), organizational deviance behaviors increases. In conclusion, ambition and grudge may be accepted as personal characteristics that lead to deviance. But it is clear that organizational environment paves the way for these characteristics to emerge. Whatever stated as the reasons for it, as a reaction to sabotage teachers stated that they just warned that person. The school, in which this study was conducted, was a rural primary school. The owner of state schools is everybody. However, when any negative behavior emerges at the state schools, no one takes responsibility. In fact, everybody needs to possess public property and protect it as if it was his own. For this reason, behaviors that may result in serious problems like sabotage should not be passed over with just a warning. It is important to give psychological support to that teacher showing this behavior in order to both guarantee schools effectiveness and existence of school property, and for teachers and students well being.

According to the findings, the third theme emerged was political deviance. Political deviance includes behaviors that may lead other employees to be disadvantageous. According to the findings, teachers experience political deviance as gossip and favoritism. Other possible political deviance behaviors are accusing employees because of employer's own fault, unnecessary rivalry, requests from employees other than work definitions, humiliating someone when the other employees are there, treating unfairly, making any kind of discrimination, being prejudice, being rude, and criticizing destructively (Arbak et al., 2004; Robinson and Bennet, 1995). In political deviance, teachers showed bad temper as the reason of gossip. Bad temper leading to deviance may be related to emotional exhaustion or decrease in working life quality (Brienza and Bobocel, 2017; Enwereuzor et al., 2017; Sezici, 2014). On the other hand, if bad temper is accepted as a personal characteristic, it provides basic conditions for organizational deviance behaviors (O'Neill et al., 2011). The reason of bad temper comes from either the nature of the work or a personal characteristic, as a result, the existence of the person that shows deviant behavior gives harm to whole organization as Dunlop and Lee (2004) stated. 
According to the research findings, as a reaction to gossip, teachers supported the person who was talked about and tried to communicate who gossiped. In Turkish society there is a general tendency like supporting the weaker, supporting the person who is talked about resembles that example and may explain the situation. Besides, communication may help to understand the conditions for gossip and give a chance to remind gossip is a wrong behavior. Moreover, the other behavior seen under political deviance was favoritism. According to the research findings, favoritism was seen in administrative processes and as the reason of it using the birth city as a common ground was shown. Whatever its reasons are, if there is some space for favoritism in administration, it means that power and authority are not used effectively. Lawrence and Robinson (2007) suggest that influence as a kind of organizational power may result in political deviance behaviors. Because of using power unfairly and not having a chance to express oneself may show itself as deviance (Lawrence and Robinson, 2007; Sims, 2010). According to the findings, as a reaction to favoritism, teachers supported the person who was not favored. In a sense, teachers tried to compensate for fairness, which was not ensured through administrative processes. Related research indicates that unfair organizational environments lead to deviance (Alias et al., 2011; Ayazlar and Guzel, 2013; Brienza and Bobocel, 2017; Yesiltas et al., 2012). For this reason, in order to ensure teachers commitment and contribution, this subject needs to be paid attention and all teachers should be treated fairly.

According to the findings, the last theme emerged was personal aggressiveness. Personal aggressiveness included aggressive and hostile behaviors shown to other employees. According to the findings, teachers experienced personal aggressiveness as stealing colleagues' ideas. Other possible personal aggressiveness behaviors are verbal harassment, firing workers unfairly, sexual harassment, not giving workers' earnings, stealing from workers', insulting (Arbak et al. 2004, Robinson and Bennet, 1995). As the reason of stealing colleagues' idea, inadequacy was shown. According to Adler (2002), the feeling of inadequacy is a stubborn illness and it exists until a need is satisfied or a tension is diminished. This innocent explanation can be a basis for stealing colleagues' ideas. On the other hand, on organizational deviance framework, personal aggressiveness is on the individual level and it is on high or serious level. In other words, behaviors called as personal aggressiveness as theft, harassment etc. are deviance on borders and can be called as a crime. For this reason, whatever explanation is given to it, these behaviors need to be treated carefully. In Turkey, teachers start to work in the state school, after having enough points in a multiple choice questions test. This may lead to miss such personality problems. In recent years, some kind of interview has been made related to teachers' appointments. However, these interviews are quite far away from being objective and do not avoid such problems. If needed before their appointment process or during their teaching profession teachers may take regular psychological health tests. In this way, it may prevent bad examples and shadows on the teaching profession. As a reaction to stealing colleagues' ideas, a warning was shown. Such kind of deviant behaviors are quite critical since they possibly result is important negative outcomes. For this reason, it should be treated in this sense.

\section{References}

Adler, A. (2002). Sosyal duygunun gelisiminde bireysel psikoloji. (Cev. H. Ozgu). İstanbul: Hayat publication.

Aksu, A. (2016). Organizational deviance and multi-factor leadership. Educational Research and Review, 11(8), 589-597. https://doi.org/10.5897/ERR2016.2671

Aksu, A., Gucer, H., \& Orcan, A. (2015). Primary school teachers' views about supervisional deviant behaviors. Educational Research and Reviews, 10(11), 1514-1523. https://doi.org/10.5897/ERR2014.2047

Akyuz, M., \& Ozyer, K. (2016). The Impact of gender discrimination on organizational deviation behavior: A Study on Health Institutions. The Journal of Organizational Behavior Research, 1(2), 53-76.

Alias, M., Rasdi, R. M., \& Said, A. A. (2011). The impact of negative affectivity, job satisfaction and interpersonal justice on workplace deviance in the private organizations. Pertanika Journals, Social Sciences and Humanities, 20(3), 829-846.

Appelbaum, S. H., İaconi, G. D., \& Matousek, A. (2007). Positive and negative deviant workplace behaviors: Causes, impacts and solutions. Corporate Governance: The International Journal of Business in Society, 7(5), 586-598. https://doi.org/10.1108/14720700710827176

Arbak, Y., Sanli, A. S., \& Cakar, U. (2004). İsyerinde sapkin davranis: akademik personel uzerinde yerel bir tanim ve tipoloji calismasi. Yonetim Arastirmalari Dergisi, 4(1), 5-24.

Argon, T., \& Ekinci, S. (2016). Teachers' views on organizational deviance, psychological ownership and social innovation. Universal Journal of Educational Research, 4(12A), 133-139. https://doi.org/10.13189/ujer.2016.041317

Ayazlar, G., \& Guzel, B. (2013). The effect of organizational justice towards workplace deviant behavior and job quit intention of hotel employees. Journal of Travel and Hospitality, 10(3), 6-23. 
Bayin, G., \& Terekli-Yesilaydin, G. (2014). Analysis of nurses' organizational deviant behavior: an example of a university hospital. Journal of Business Research Turk, 6(3), 81-107. https://doi.org/10.20491/isader.2014315941

Bennett, R. J., \& Robinson, S. L. (2000). Development of a measure of workplace deviance. Journal of Applied Psychology, 85(3), 349-360. https://doi.org/10.1037/0021-9010.85.3.349

Brienza, J. P., \& Bobocel, D. R. (2017). Employee age alters the effects of justice on emotional exhaustion and organizational deviance. Frontiers in Psychology, 8(479), 1-15. https://doi.org/10.3389/fpsyg.2017.00479

Buyukozturk, S., Kilic-Cakmak, E., Akgun, O. E., Karadeniz, S., \& Demirel, F. (2012). Bilimsel arastirma yontemleri (11. Baski). Ankara: Pegem Akademi.

Celikten, M., Sanal, M., \& Yeni, Y. (2005). Ogretmenlik meslegi ve ozellikleri. Erciyes Universitesi Sosyal Bilimler Enstitusu Dergisi, 19(2), 207-237.

Christensen, L. B., Johnson, R. B., \& Turner, L. A. (2015). Arastirma yontemleri: Desen ve Analiz. (Cev. Ed.: A. Aypay). Ankara: Ani Yayincilik.

Daymon, C., \& Holloway, İ. (2002). Qualitative Research Methods in Public Relations and Marketing Communications. London: Routledge.

Demir, M. (2010). The role of emotional intelligence on the control of organizational deviance: a survey in the hospitality enterprises. Dumlupinar University Journal of Social Sciences, 26(1), 196-207.

Demir, M., \& Tutuncu, O. (2010). Relationship between organizational deviance and turnover intentions in hospitality businesses. Anatolia: Turizm Arastirmalari Dergisi, 21(1), 64-74.

Dobbert, D. L., \& Mackey, T. X. (2015). (Edits). Deviance, theories on behaviors that defy social norms. California: Praeger.

Dunlop, P. D., \& Lee, K. (2004). Workplace deviance, organizational citizenship behavior, and business unit performance: The bad apples do spoil the whole barrel. Journal of Organizational Behavior, 25, 67-80. https://doi.org/10.1002/job.243

Enwereuzor, İ. K., Onyishi, İ. E., Onyebueke, İ. F., Amazue L. O., \& Nwoke, M. B. (2017) Personality as a moderator between emotional exhaustion and workplace deviance among teachers. Journal of Psychology in Africa, 27(1), 41-46.

Franzese, R. J. (2015). The sociology of deviance, difference, tradition and stigma. İllinois: Charles C Thomas Publishers, Ltd.

Girgin-Kose, S., \& Aksu, A. (2013). Organizational deviation measurement for schools. E-Journal of New World Sciences Academy, 8(3), 375-389.

Goode, E. (2015). (Edt.) The handbook of deviance. Malden: Wiley. https://doi.org/10.1002/9781118701386

Guay, R. P., Choi, D., Oh, İ. S., Mitchell, M. S., Mount, M. K., \& Shin, K. H. (2010). Why people harm the organization and its members: Relationships among personality, organizational commitment, and workplace deviance. Human Performance, 29(1), 1-15. https://doi.org/10.1080/08959285.2015.1120305

Hollinger, R. C., \& Clark, J. (1982). Formal and informal social controls of employee deviance. The Sociological Quarterly, 23, 333-343. https://doi.org/10.1111/j.1533-8525.1982.tb01016.x

İyigun, N. O., \& Cetin, C. (2012). The Impact of psychological contract on organizational deviance and a research in pharmaceutical sector. Oneri, 10(37), 15-29.

Kaplan, H. B. (1975). Self-attitudes and deviant behavior. Pacific Palisades: Goodyear.

Lawrence, T. B., \& Robinson, S. L. (2007). Ain’t misbehavin: Workplace deviance as organizational resistance. Journal of Management, 33(3), 378-394. https://doi.org/10.1177/0149206307300816

Mangione T. W., \& Quinn, R. P. (1975). Job satisfaction, counterproductive behavior and drug use at work. Journal of Applied Psychology, 1, 114-116. https://doi.org/10.1037/h0076355

Miles, M. B., \& Huberman, B. A. (1994). Qualitative data analysis: an expanded sourcebook. (2nd Ed.). Newbury Park, CA: Sage.

O’Neill, T. A., Lee, N. M., Radan, J., Law, S. J., Lewis, R. J., \& Carswell, J. J. (2013). The impact of "non-targeted traits" on personality test faking, hiring and workplace deviance. Personality and Individual Differences, 56, 162-168. https://doi.org/10.1016/j.paid.2013.02.027

O’Neill, T. A., Lewis, R. J., \& Carswell, J. J. (2011). Employee personality, justice perceptions and the prediction of 
workplace deviance. Personality and Individual Differences, 51, 595-600. https://doi.org/10.1016/j.paid.2011.05.025

QSR International. (2012). What is NVIVO? Retrieved on 04.08.2017 from http://www.qsrinternational.com/what-is-nvivo

Richardson, M. (2000). Writing a method of inquiry. Handbook of qualitative research. (2 ${ }^{\text {nd }}$. Ed.). Edits Norman K. D. and Yvonna S. L. Thousand Oaks, CA: Sage, 923-948.

Robbinson, S. L., \& Bennet, R. J. (1995). A typology of deviant workplace behaviors: a multidimensional scaling study. Academy of Management Journal, 38(2), 555-572. https://doi.org/10.2307/256693

Sezici, E. (2014). Relationship among quality of work life, workplace deviance and turnover intention. Dumlupinar University Journal of Social Sciences, 41, 235-246.

Sims, R. L. (2010). A study of deviance as a retaliatory response to organizational power. Journal of Business Ethics, 92 , 553-563. https://doi.org/10.1007/s10551-009-0172-3

Traub, S. H., \& Little, C. B. (1999). (Edts). Theories of deviance. Illlinois: Peacock Publishers.

Turkkas-Anasiz, B. (2016). A Study on Determination of the Organizational Deviant Behaviors of Academic Staff (A Case of Education Faculty of Mugla Sitk1 Kocman University). (Unpublished Master Thesis). Mugla Sitki Kocman University, Institute of Educational Sciences, Mugla-Turkey.

Waterhouse, S. (2004). Deviant and non-deviant identities in the classroom: patrolling the boundaries of the normal social world. European Journal of Special Needs Education, 19(1), 69-84. https://doi.org/10.1080/0885626032000167151

Yesiltas, M., Ceken, H., \& Sormaz, U. (2012). Ethical leadership and organizational justice on the effect of organizational workplace deviation. Mugla University Journal of Social Sciences Institute, 28, 18-39.

Yildirim, A., \& Simsek, H. (2011). Sosyal bilimlerde nitel arastirma yontemleri. Ankara: Seckin.

\section{Copyrights}

Copyright for this article is retained by the author(s), with first publication rights granted to the journal.

This is an open-access article distributed under the terms and conditions of the Creative Commons Attribution license which permits unrestricted use, distribution, and reproduction in any medium, provided the original work is properly cited. 